\title{
Effect of composition and joining parameters on microstructure and mechanical properties of silicon carbide joints
}

\author{
Wubian TIAN, ${ }^{\dagger}$ Hideki KITA, Naoki KONDO, Hideki HYUGA and Takaaki NAGAOKA
}

National Institute of Advanced Industrial Science and Technology (AIST), 2266-98 Shimo-Shidami, Moriyama-ku, Nagoya 463-8560

\begin{abstract}
Powder- and tape-like joining materials composed of $\mathrm{SiC}$ with $\mathrm{Al}-\mathrm{B}-\mathrm{C}$ (ABC) or $\mathrm{Al}-\mathrm{B}_{4} \mathrm{C}-\mathrm{C}$ (ABCC) sintering additives were used for the joining of $\mathrm{SiC}$. The effect of interlayer composition, joining temperature and particle size of $\mathrm{SiC}$ on the microstructure and mechanical properties of $\mathrm{SiC}$ joints was studied. The results indicated that the tape-like adhesive introduces denser microstructure of interlayer relative to the powder-like one under the same conditions. It was demonstrated that using fine starting $\mathrm{SiC}$ powder instead of coarse one enhances the densification process of $\mathrm{SiC}$ joints. As joined at $1650^{\circ} \mathrm{C}$, the microstructure of interlayer is improved gradually with the increasing Al content from 1 to $6 \mathrm{wt} \%$ in composition while slightly affected by the forms of additives, i.e. ABCC additive having the equal action to ABC one on the densification of joints. At higher joining temperature of $1750^{\circ} \mathrm{C}$, the microstructure of interlayer containing $3 \mathrm{wt} \%$ Al almost does not change while that containing $6 \mathrm{wt} \%$ degrades. SiC joints with strength higher than $344 \mathrm{MPa}$ have been produced by using optimized joining variables, where the fracture of bonded $\mathrm{SiC}$ generally occurs within the $\mathrm{SiC}$ substrate.
\end{abstract}

๑2010 The Ceramic Society of Japan. All rights reserved.

Key-words : Silicon carbide, Joints/joining, Microscopy, Mechanical properties

[Received April 1, 2010; Accepted May 20, 2010]

\section{Introduction}

Silicon carbide $(\mathrm{SiC})$ is one of the most extensively studied and widely used compounds because of its combination of exceptional properties, such as good mechanical properties (high hardness, strength and elastic modulus), low thermal expansion coupled with high thermal conductivity, superior chemical inertness and so on. ${ }^{1)-3)}$ Due to the low self-diffusion coefficient and high energy of grain boundaries, however, the densification of $\mathrm{SiC}$ is difficult to accomplish if without sintering additives or high external pressure. $\left.{ }^{4}\right)$ Many investigations have been done to find appropriate additives for SiC sintering. In the mid-1970's, Prochazka et al. ${ }^{5), 6)}$ firstly introduced pressureless solid-state sintering of $\mathrm{SiC}$ with boron and carbon sintering-aids. This solidstate sintering process, however, usually results in materials with low fracture toughness and requires high processing temperature $\left(>2100^{\circ} \mathrm{C}\right)$ that easily leads to exaggerated grain growth. Instead, a liquid-phase sintering process was developed by adding aluminum to $\mathrm{B}-\mathrm{C}$ additions to lower densification temperature. ${ }^{7)}$ It was demonstrated that $\mathrm{SiC}$ ceramics can be densified at temperatures lower than $1900^{\circ} \mathrm{C}$ with $\mathrm{Al}-\mathrm{B}-\mathrm{C}$ additives. The sintered $\mathrm{SiC}$ shows improved ambient-temperature fracture toughness and strength, ${ }^{8), 9)}$ and stable high-temperature toughness/creep behavior at temperatures up to $1300^{\circ} \mathrm{C}{ }^{10)}$ Effect of the forms of sintering additives in $\mathrm{Al}-\mathrm{B}-\mathrm{C}$ system, e.g. $\mathrm{AlB}_{2}-\mathrm{C}$, $\mathrm{Al}_{3} \mathrm{BC}_{3}$ and $\mathrm{Al}_{8} \mathrm{~B}_{4} \mathrm{C}_{7}$, on the microstructure, densification and mechanical properties of sintered $\mathrm{SiC}$ were also studied. ${ }^{11)-14)}$

Nowadays, $\mathrm{SiC}$ parts with small size and simple shape are commercially available. While specific desire for large-sized and complex-shaped $\mathrm{SiC}$ components increases with the development of advanced industry. Joining of $\mathrm{SiC}$ parts is one of the promising and effective approaches to produce $\mathrm{SiC}$ components. ${ }^{15), 16)}$ For instance, $\mathrm{SiC}$ substrates sintered with $\mathrm{B}-\mathrm{C}$ additions were

\footnotetext{
Corresponding author: W. B. Tian; E-mail: w.b.tian@aist.go.jp
}

diffusion bonded at $1950^{\circ} \mathrm{C}$ with $14 \mathrm{MPa}$ and the bending strength of joints reaches $300 \mathrm{MPa}{ }^{17)}$ Other attempts contain the joining of $\mathrm{SiC}$ in the green state followed by sintering with or without pressure and prepared $\mathrm{SiC}$ joints show strengths up to $323 \mathrm{MPa}{ }^{18), 19)}$ Furthermore, it is well known that the mechanical strength of joint depends on the weakest part, mostly the interface between interlayer and substrate. If one wants to produce high strength $\mathrm{SiC}$ joints, therefore, the joining interlayer should possess high strength and the thermal mismatch at interface should be minimized. SiC powder mixed with $\mathrm{Al}-\mathrm{B}-\mathrm{C}$ additions is definitely a good choice for the joining of $\mathrm{SiC}$ bodies based on abovementioned literatures. In fact, this system had been used for the joining of two dense $\mathrm{SiC}$ sintered bodies ${ }^{20), 21)}$ and bonding strength up to $530 \mathrm{MPa}$ was achieved by hot-pressing at a temperature as low as $1650^{\circ} \mathrm{C}$ for $30 \mathrm{~min}$ under $50 \mathrm{MPa}$ pressure. The effect of the composition of additive and the impurities in $\mathrm{SiC}$ sintered body on the microstructure and mechanical properties of $\mathrm{SiC}$ joints were investigated. These results point to a fact that the powder mixture of $\mathrm{SiC}$ with $\mathrm{Al}-\mathrm{B}-\mathrm{C}$ additives is suitable for the joining of SiC-based ceramics.

However, the influences of starting $\mathrm{SiC}$ powders, the forms of sintering additives $\left(\mathrm{Al}-\mathrm{B}-\mathrm{C}\right.$ or $\left.\mathrm{Al}-\mathrm{B}_{4} \mathrm{C}-\mathrm{C}\right)$ and the preparation method of joining materials (power mixtures or tapes) as well as the joining process on the microstructure and properties of bonded $\mathrm{SiC}$ are not elaborated in detail. In the present work, therefore, we focus on the relationship between interlayer microstructure and abovementioned influencing factors by conducting $\mathrm{SiC}$ joining tests in the temperature range of 1650 $1850^{\circ} \mathrm{C}$ for $30-60 \mathrm{~min}$ under mechanical pressure of $12.5-$ $50 \mathrm{MPa}$, with the objective of producing high-strength $\mathrm{SiC}$ joints.

\section{Experimental procedure}

\subsection{Joining materials preparation}

The characteristics of used powders, including silicon carbide, aluminum, boron, boron carbide and carbon, were listed in 
Table 1. Characteristics of starting powders

\begin{tabular}{|c|c|c|c|c|c|}
\hline Powder & $\begin{array}{l}\text { Purity } \\
(\%)\end{array}$ & $\begin{array}{l}\text { D50 } \\
(\mu \mathrm{m})\end{array}$ & $\begin{array}{l}\text { S.S.A } \\
\left(\mathrm{m}^{2} / \mathrm{g}\right)\end{array}$ & $\begin{array}{l}\text { Major impurities } \\
\text { (elements/wt \%) }\end{array}$ & Maker \\
\hline A-2 $(\alpha-\mathrm{SiC})$ & 98 & 0.60 & 12 & $\mathrm{C} / 1.0, \mathrm{SiO}_{2} / 0.6$ & Showa Denko, Tokyo, Japan \\
\hline A-1 $(\alpha-\mathrm{SiC})$ & 97 & 0.48 & 17 & $\mathrm{C} / 1.4, \mathrm{SiO}_{2} / 0.7$ & Showa Denko, Tokyo, Japan \\
\hline$\beta-\mathrm{SiC}$ & - & ultrafine & - & - & Ibiden Corp., Japan \\
\hline $\mathrm{Al}$ & 99.9 & 20 & - & $\mathrm{Si} / 0.03, \mathrm{Fe} / 0.06$ & Kojundo Chemical Lab., Japan \\
\hline B & 99 & $<45$ & - & $\mathrm{Si} / 0.1, \mathrm{Fe} / 0.07$ & Kojundo Chemical Lab., Japan \\
\hline $\mathrm{B}_{4} \mathrm{C}$ & HS grade & 0.63 & 20 & $\mathrm{Si} / 0.1, \mathrm{Fe} / 0.01$ & H. C. STARCK, Germany \\
\hline $\mathrm{C}$ & 99.7 & 5 & - & $\mathrm{Fe} / 0.1, \mathrm{Ca} / 0.03$ & Kojundo Chemical Lab., Japan \\
\hline
\end{tabular}

— Data unknown

Table 2. Sample label, composition of sintering additive and joining process of bonded $\mathrm{SiC}$ ceramics

\begin{tabular}{|c|c|c|c|c|c|c|}
\hline \multirow{2}{*}{ Sample label } & \multirow{2}{*}{$\begin{array}{l}\text { Starting } \\
\mathrm{SiC}\end{array}$} & \multicolumn{4}{|c|}{ Amount of additive (wt \%) } & \multirow{2}{*}{$\begin{array}{l}\text { Joining process } \\
\left({ }^{\circ} \mathrm{C} / \mathrm{MPa} / \mathrm{min}\right)\end{array}$} \\
\hline & & $\mathrm{Al}$ & B & $\mathrm{B}_{4} \mathrm{C}$ & $\mathrm{C}$ & \\
\hline A1BC65 & A-2 & 1 & 1 & 0 & 1 & $1650 / 50 / 30$ \\
\hline A3BC65 & A-2 & 3 & 1 & 0 & 1 & $1650 / 50 / 30$ \\
\hline A6BC65 & A-2 & 6 & 1 & 0 & 1 & $1650 / 50 / 30$ \\
\hline A3BC75 & A-2 & 3 & 1 & 0 & 1 & $1750 / 12.5 / 30$ \\
\hline $\mathrm{A} 6 \mathrm{BC} 75$ & A-2 & 6 & 1 & 0 & 1 & $1750 / 12.5 / 30$ \\
\hline T-A6BC75* & $\mathrm{A}-2$ & 6 & 1 & 0 & 1 & $1750 / 12.5 / 30$ \\
\hline T-A6BC $80^{*}$ & $\mathrm{~A}-2$ & 6 & 1 & 0 & 1 & $1800 / 12.5 / 30$ \\
\hline A6BCC65 & A-2 & 6 & 0 & 1.3 & 0.7 & $1650 / 50 / 30$ \\
\hline$\alpha-\mathrm{A} 6 \mathrm{BCC} 65$ & A-1 & 6 & 0 & 1.3 & 0.7 & $1650 / 50 / 30$ \\
\hline$\beta$-А6BCC65 & $\beta$-SiC & 6 & 0 & 1.3 & 0.7 & $1650 / 50 / 30$ \\
\hline
\end{tabular}

*Joining materials was prepared using tape casting method.

Table 1. Two forms of sintering additives were used (namely Al$\mathrm{B}-\mathrm{C}$ and $\mathrm{Al}-\mathrm{B}_{4} \mathrm{C}-\mathrm{C}$ system), as summarized in Table 2, where the labels of bonded samples and joining processes were also presented.

$\mathrm{SiC}$ powders were mixed with sintering additives by ball milling for $24 \mathrm{~h}$ using silicon carbide balls as media. The powder-like joining materials were mixed in ethanol and then dried using a vacuum evaporator. For the joining materials prepared by tape casting procedure, powder mixtures were dispersed with fuloren G700 (Kyoeisha Chemical Co., Japan) in a solvent of toluene and butanol, where polyvinybutyral (PVB) and dioctyl adipate (DOA) were used as the binder and plasticizer, respectively. Tape casting was conducted in a doctor blade (DR-150, Sayama Co. Ltd., Japan) with a blade gap of $250 \mu \mathrm{m}$ and at a speed of $100 \mathrm{~mm} / \mathrm{min}$. The thickness of dry tape was about $60 \mu \mathrm{m}$ and the green density was around $1.8 \mathrm{~g} / \mathrm{cm}^{3}$ determined by the weight and size of tape.

\subsection{Joining method}

$\mathrm{SiC}$ sintered bodies used in present study were purchased from company (Covalent Materials Co., Japan) with a density of $3.1 \mathrm{~g} / \mathrm{cm}^{3}$ and a room-temperature bending strength of $450 \mathrm{MPa}$. $\mathrm{SiC}$ plates were cut into a dimension of $20 \times 20 \times 3 \mathrm{~mm}$ or $20 \times 20 \times 20 \mathrm{~mm}$ and used for joining tests. Prior to joining, $\mathrm{SiC}$ plate surface $(20 \times 20)$ was polished down to $0.5 \mu \mathrm{m}$ and ultrasonically cleaned in ethanol. The powder- or tape-like joining materials were sandwiched between two polished SiC plates. Joining procedures were performed in a graphite elements furnace with $1 \mathrm{~atm}$ flowing $\mathrm{Ar}$ and proceeded in the temperature range of $1650-1850^{\circ} \mathrm{C}$ for $30-60$ min under mechanical pressure of $12.5-50 \mathrm{MPa}$.

\subsection{Microstructure characterization}

The joined $\mathrm{SiC}$ samples were sectioned perpendicular to the interlayer and polished to $0.5 \mu \mathrm{m}$ diamond suspensions. Microstructure observations on the polished surfaces were conducted via SEM (JSM-5600, JEOL, Japan).

\subsection{Mechanical properties measurements}

Room temperature 4-point bending strength was measured on $4 \times 3 \times 40 \mathrm{~mm}$ beams with outer and inner span of 30 and $10 \mathrm{~mm}$, respectively, at a crosshead speed of $0.5 \mathrm{~mm} / \mathrm{min}$. The tensile surface was polished down to $0.5 \mu \mathrm{m}$ diamond suspension and the edges of tested specimens were beveled. At least five specimens were used for each strength determination.

\section{Results and discussion}

\subsection{Al-B-C system}

3.1.1 Effect of the composition of sintering additive on the microstructure of SiC interlayer

$0.2 \mathrm{~g}$ powder mixtures of $\alpha$-SiC (A-2) and Al-B-C additives with 1,3 and $6 \mathrm{wt} \% \mathrm{Al}$ (i.e. $\mathrm{A} 1 \mathrm{BC}, \mathrm{A} 3 \mathrm{BC}$ and $\mathrm{A} 6 \mathrm{BC}$ ) were firstly used as joining materials. The joining process was conducted at $1650^{\circ} \mathrm{C}$ for $30 \mathrm{~min}$ under $50 \mathrm{MPa}$, referring to that used by Iseki et al. ${ }^{21)}$ The SEM images of polished cross-sections of bonded $\mathrm{SiC}$ are presented in Fig. 1(a) through (c), from which it is clear that the microstructure of interlayer improves greatly from $\mathrm{A} 1 \mathrm{BC}$ to $\mathrm{A} 3 \mathrm{BC}$ and further increasing the $\mathrm{Al}$ content in sintering additives has slight influence on the microstructure of interlayer.

The formation of a second phase $\mathrm{Al}_{8} \mathrm{~B}_{4} \mathrm{C}_{7}$ is considered to be contributed to lower sintering temperature ${ }^{21)}$ and a coexisted liquid phase with $\mathrm{Al}_{8} \mathrm{~B}_{4} \mathrm{C}_{7}$ enhances the densification of $\mathrm{SiC}{ }^{22)}$ If assuming the formation of $\mathrm{Al}_{8} \mathrm{~B}_{4} \mathrm{C}_{7}$ in interlayer, $\mathrm{A} 1 \mathrm{BC}$ contains excess boron and carbon while $\mathrm{A} 3 \mathrm{BC}$ and $\mathrm{A} 6 \mathrm{BC}$ consist of excess aluminum and boron that form a liquid phase and accelerate the densification process.

\subsubsection{Lowering the joining pressure by increasing joining temperatures}

To decrease the joining pressure required for good joint microstructure, we adjust the joining temperature from 1650 to $1750^{\circ} \mathrm{C}$ and simultaneously lower the pressure to $12.5 \mathrm{MPa}$. The SEM micrographs of A3BC and A6BC cross-sections are shown in Fig. 2(a) and (b). It is found that the microstructure of interlayer in $\mathrm{A} 3 \mathrm{BC}$ improves slightly with the joining temperature. In contrary, degraded microstructure of interlayer is observed in $\mathrm{A} 6 \mathrm{BC}$, in which the amount and the size of pores in interlayer increase significantly as joined at $1750^{\circ} \mathrm{C}$.

Undoubtedly, the more the $\mathrm{Al}$ content and the more the quantity of liquid phase formed from excess aluminum and boron. When the amount of liquid phase is relatively low (A3BC), the interlayer would be further densified at higher 

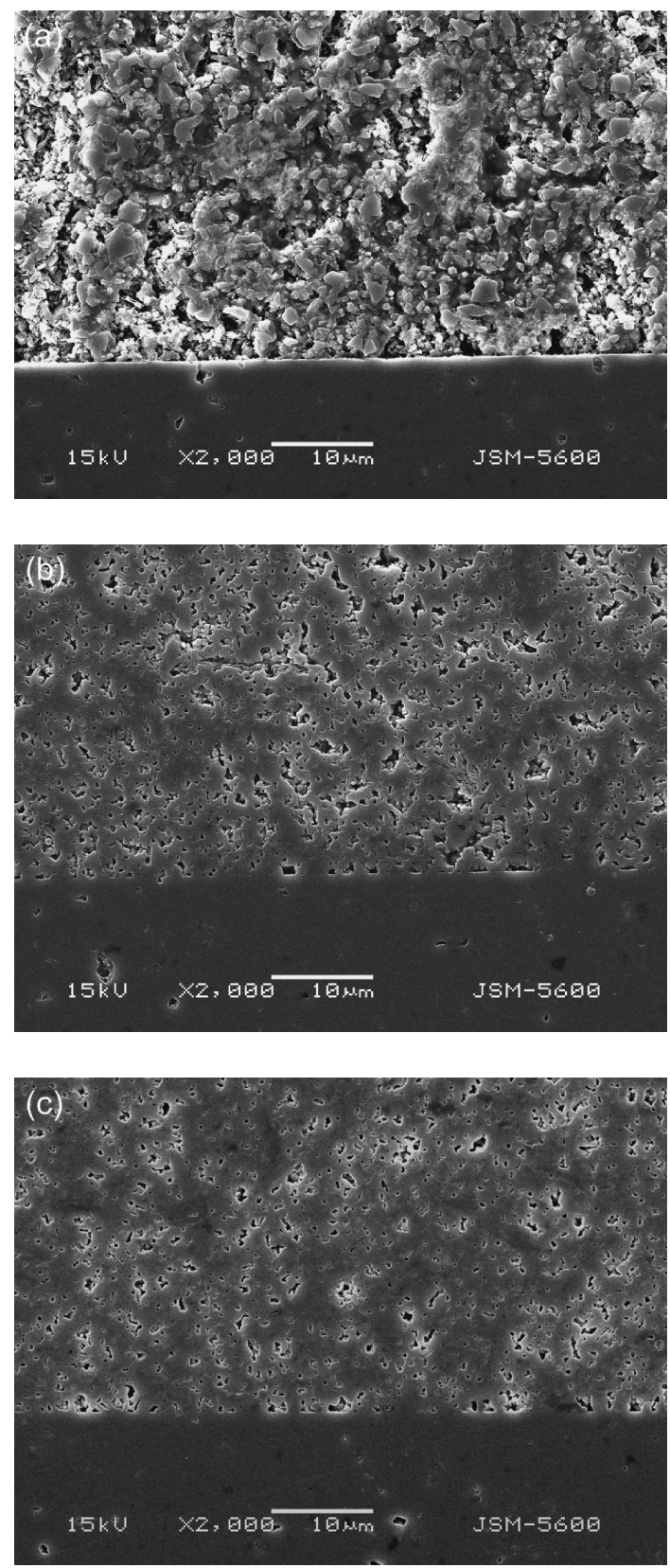

Fig. 1. SEM images of the polished cross-sections of $\mathrm{SiC}$ joints (a) A1BC65, (b) A3BC65 and (c) A6BC65. Joining materials: $\alpha-\mathrm{SiC}$ (A-2) with $\mathrm{Al}-\mathrm{B}-\mathrm{C}$ additives; joining process: at $1650^{\circ} \mathrm{C}$ for $30 \mathrm{~min}$ under $50 \mathrm{MPa}$.

joining temperature. When the liquid-phase content is too high (A6BC), however, the grain growth will compete with and prevail over the densification of $\mathrm{SiC}$ interlayer at higher temperature $\left(1750^{\circ} \mathrm{C}\right)$, because the grains grow rapidly and form a rigid skeleton that retards further densification. ${ }^{11)}$

\subsubsection{Comparison between powder- and tape-like} A6BC joining materials for the joining of $\mathrm{SiC}$

To compare with the powder-like $\mathrm{A} 6 \mathrm{BC}$ and decrease the interlayer thickness, tape-like A6BC (T-A6BC) was applied as joining materials for the joining of $\mathrm{SiC}$. At a joining temperature of $1750^{\circ} \mathrm{C}$, a denser interlayer is obtained by using T-A6BC (Fig. 3(a)) if compared with that of powder-like A6BC (Fig. 2(b)). As the joining temperature increases to $1800^{\circ} \mathrm{C}$, the interlayer density of $\mathrm{SiC}$ joint is improved significantly, as
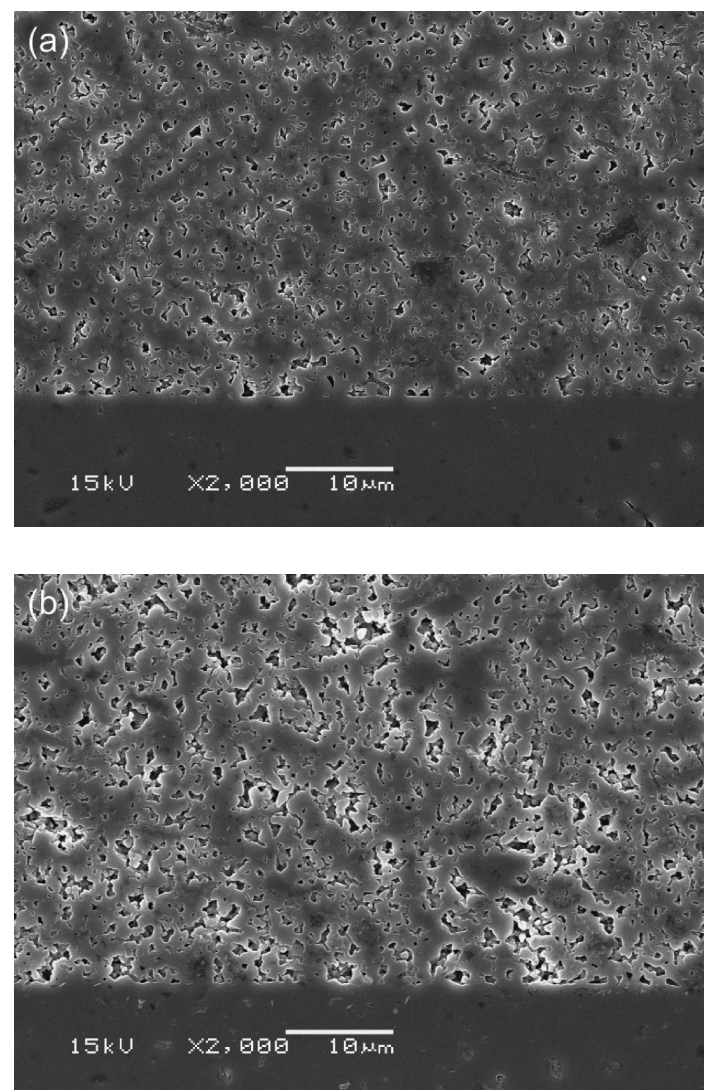

Fig. 2. SEM micrographs of the polished interlayer of $\mathrm{SiC}$ joints (a) A3BC75 and (b) A6BC75. Joining materials: $\alpha$-SiC (A-2) with Al-B$\mathrm{C}$ additives; joining process: at $1750^{\circ} \mathrm{C}$ for $30 \mathrm{~min}$ under $12.5 \mathrm{MPa}$.

shown in Fig. 3(b), in which the pores inside interlayer are diminished greatly and some areas between interlayer and $\mathrm{SiC}$ substrate are bonded together.

For the joining of $\mathrm{SiC}$, several kinds of interlayer materials prepared by using tape casting method have been described ${ }^{23)-25)}$ and uniform interlayer was obtained by optimizing the tape casting process and joining variables. In present study, the good joint microstructure is believed to be mainly attributed to the uniform and thin joining materials. Additionally, a small amount of residual carbon left after debinding process could also affect the composition of sintering additives and subsequently the joining process. Similar phenomenon was observed and elaborately investigated for the sintering of tape-cast $\mathrm{AlN},{ }^{26), 27)}$ in which the residual carbon from binder burnout shows correlation with the sintering behavior, the composition and distribution of secondary phases and grain-boundary composition of AlN samples.

\section{$3.2 \mathrm{Al}-\mathrm{B}_{4} \mathrm{C}-\mathrm{C}$ system}

\subsubsection{Using $\mathrm{SiC}$ powder mixture with $\mathrm{Al}-\mathrm{B}_{4} \mathrm{C}-\mathrm{C}$ additives for the joining of $\mathrm{SiC}$}

Note that the particle size of boron in Al-B-C system is apparently coarser than that of aluminum and carbon. A new system of $\mathrm{Al}-\mathrm{B}_{4} \mathrm{C}-\mathrm{C}$ using finer and cheaper $\mathrm{B}_{4} \mathrm{C}$ instead of $\mathrm{B}$ was applied for the $\mathrm{SiC}$ joining. The selected composition of sintering additive is $\mathrm{Al}: \mathrm{B}_{4} \mathrm{C}: \mathrm{C}=6: 1.3: 0.7$, i.e. sample $\mathrm{A} 6 \mathrm{BCC}$, which has the same composition to $\mathrm{A} 6 \mathrm{BC}(\mathrm{Al}: \mathrm{B}: \mathrm{C}=6: 1: 1)$. The polished cross-section of sample A6BCC is displayed in Fig. 4, from which we can see that the interlayer of A6BCC shows similar microstructure to that of A6BC (Fig. 1(c)), suggesting 

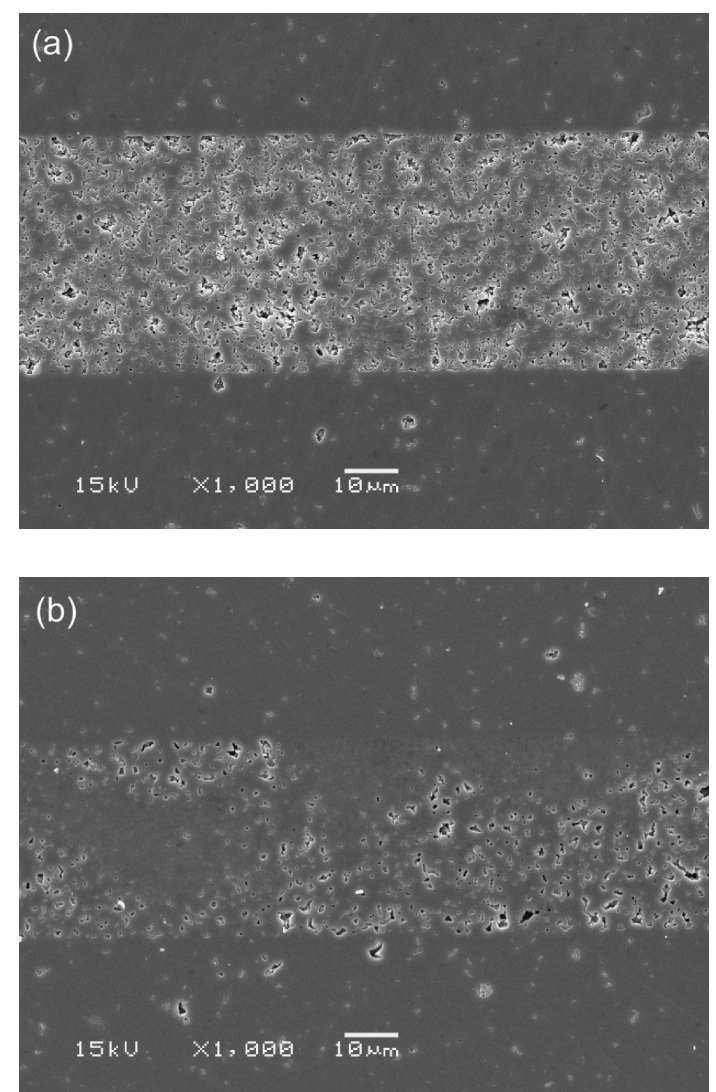

Fig. 3. Microstructure observations on the interlayer of $\mathrm{SiC}$ joints (a) T-A6BC75 and (b) T-A6BC80, where tape-like A6BC was used as joining material and joined at $1750^{\circ} \mathrm{C}$ and $1800^{\circ} \mathrm{C}$, respectively.

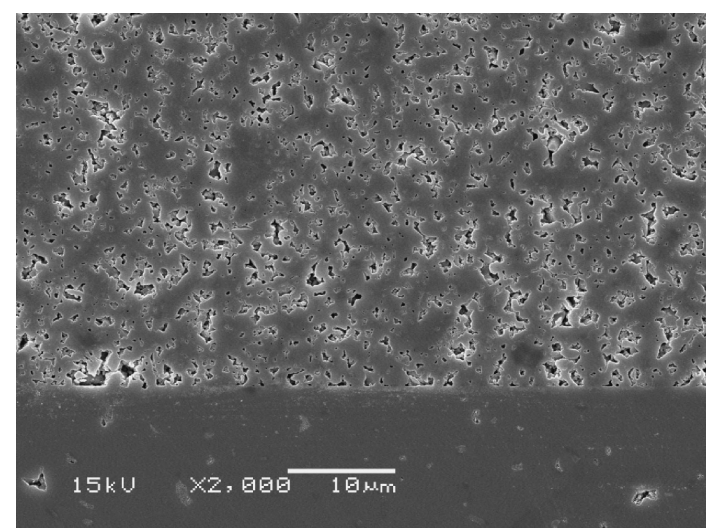

Fig. 4. The polished cross-section of sample A6BCC65 that was started from $\alpha$-SiC (A-2) with $\mathrm{Al}-\mathrm{B}_{4} \mathrm{C}-\mathrm{C}$ additives (composition of $\left.\mathrm{Al}: \mathrm{B}_{4} \mathrm{C}: \mathrm{C}=6: 1.3: 0.7\right)$ and joined at $1650^{\circ} \mathrm{C}$ for $30 \mathrm{~min}$ under $50 \mathrm{MPa}$.

that $\mathrm{B}_{4} \mathrm{C}$ has equivalent effect to that of $\mathrm{B}$ and $\mathrm{C}$ on the densification of $\mathrm{SiC}$ joint.

Studies on the chemical reactions in $\mathrm{Al}-\mathrm{B}_{4} \mathrm{C}$ and $\mathrm{Al}-\mathrm{B}-\mathrm{C}$ systems at temperatures up to $1000^{\circ} \mathrm{C}$ demonstrate that the phase equilibrium changes with the forms of starting materials even containing same elements. ${ }^{28)}$ In present study, the used sintering additives share the same composition but change the starting forms, which will affect the subsequent reaction dynamic and the intermediate products of grain-boundary phases during the joining process. However, the similar densification effect of $\mathrm{A} 6 \mathrm{BC}$ and $\mathrm{A} 6 \mathrm{BCC}$ for the joining of $\mathrm{SiC}$ suggests that the finally resulting phases of sintering additives play the same role.
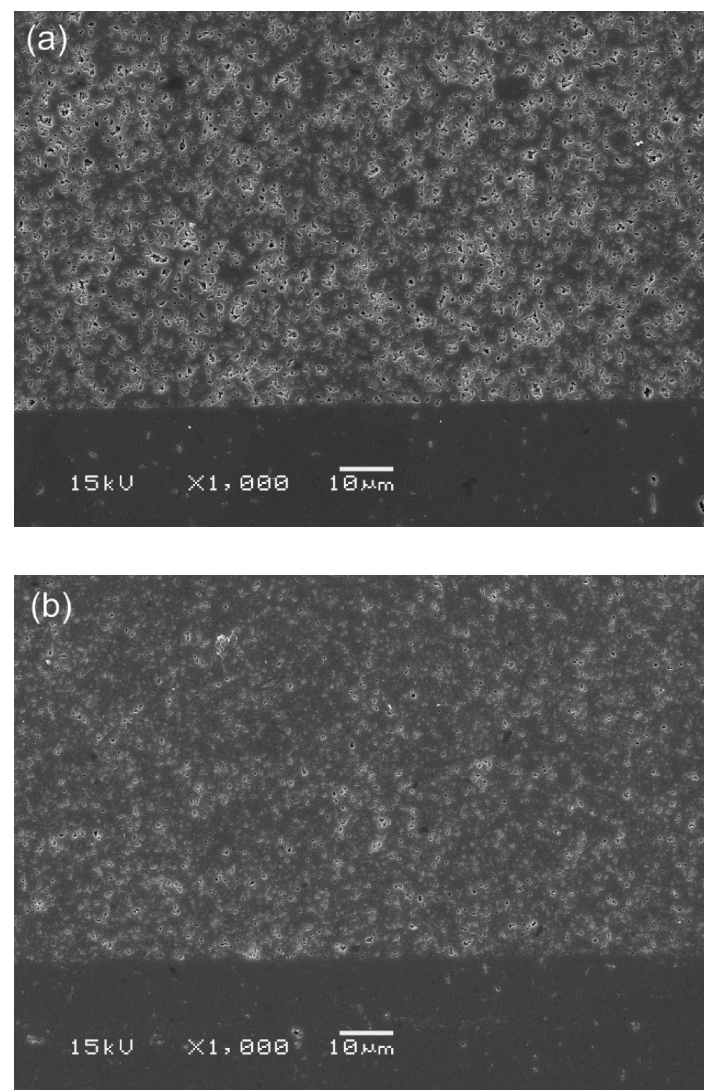

Fig. 5. SEM micrographs of the microstructure of interlayer starting from (a) $\alpha$-SiC $(\alpha-\mathrm{A} 6 \mathrm{BCC} 65)$ and (b) $\beta$-SiC $(\beta$-A6BCC65) with composition of $\mathrm{Al}: \mathrm{B}_{4} \mathrm{C}: \mathrm{C}=6: 1.3: 0.7$. Joining process: at $1650^{\circ} \mathrm{C}$ for $30 \mathrm{~min}$ under $50 \mathrm{MPa}$.

\subsubsection{Effect of starting $\mathrm{SiC}$ powder on the densi- fication of SiC interlayer}

To study the effect of starting $\mathrm{SiC}$ powder on the microstructure of interlayer, powder mixtures of submicron $\alpha$-SiC (A-1) or $\beta$-SiC with $\mathrm{Al}-\mathrm{B}_{4} \mathrm{C}-\mathrm{C}$ additives were used for the joining of $\mathrm{SiC}$ (named as $\alpha$-A6BCC or $\beta$-A6BCC, respectively). The composition of sintering additive was maintained to be $\mathrm{Al}: \mathrm{B}_{4} \mathrm{C}: \mathrm{C}=6: 1.3: 0.7$ and the joining tests were carried out at $1650^{\circ} \mathrm{C}$ for $30 \mathrm{~min}$ under $50 \mathrm{MPa}$. The SEM micrographs on polished cross-sections are shown in Fig. 5(a) and (b), from which it is clear that the densification of interlayer improves with decreasing particle size of starting $\mathrm{SiC}$ powder at this sintering temperature. This is easy to understand because the powder with finer particle size exhibits greater driving force of densification than the coarser one. ${ }^{29)}$

\subsection{Mechanical properties of SiC joints}

Present results suggest that the densification and microstructure of bonded $\mathrm{SiC}$ depend on not only the joining parameters (temperature and pressure), but also the composition (constituent of additive and starting $\mathrm{SiC}$ powder) and the preparation method of interlayer (power mixture or tapes). To sum up, i) more than $3 \mathrm{wt} \% \mathrm{Al}$ in sintering additive is beneficial to the densification of interlayer at $1650^{\circ} \mathrm{C}$ while the interlayer density is degraded at $1750^{\circ} \mathrm{C}$ if $\mathrm{Al}$ content is too high (A6BC in Fig. 2(b)), ii) tapelike joining materials show positive effect on the microstructure of interlayer provided similar joining process, iii) $\mathrm{B}_{4} \mathrm{C}$ shows equivalent effect to $\mathrm{B}$ and $\mathrm{C}$ in sintering additive on the 
Table 3. Composition of joining materials and the mechanical properties of $\mathrm{SiC}$ joints using optimized joining parameters

\begin{tabular}{|c|c|c|c|c|c|c|c|c|}
\hline \multirow[t]{2}{*}{ Sample label } & \multirow{2}{*}{$\begin{array}{l}\text { Starting } \\
\mathrm{SiC}\end{array}$} & \multicolumn{4}{|c|}{$\begin{array}{c}\text { Composition of additive } \\
\text { (wt } \% \text { ) }\end{array}$} & \multirow{2}{*}{$\begin{array}{c}\text { Joining } \\
\text { parameters } \\
\left({ }^{\circ} \mathrm{C} / \mathrm{MPa} / \mathrm{min}\right)\end{array}$} & \multirow{2}{*}{$\begin{array}{l}\text { Interlayer } \\
\text { thickness } \\
(\mu \mathrm{m})\end{array}$} & \multirow{2}{*}{$\begin{array}{c}\text { Bending } \\
\text { strength } \\
(\mathrm{MPa}) \\
\end{array}$} \\
\hline & & $\mathrm{Al}$ & $\mathrm{B}$ & $\mathrm{B}_{4} \mathrm{C}$ & $\mathrm{C}$ & & & \\
\hline$\beta$-A5BCC* & $\beta$-SiC & 5 & 0 & 1.28 & 1.72 & $1850 / 15 / 60$ & 33 & $344 \pm 25$ \\
\hline$\alpha-\mathrm{A} 5 \mathrm{BCC}^{*}$ & A-1 & 5 & 0 & 1.28 & 1.72 & $1850 / 15 / 60$ & 29 & $364 \pm 24$ \\
\hline
\end{tabular}

${ }^{*}$ Tape-like joining materials
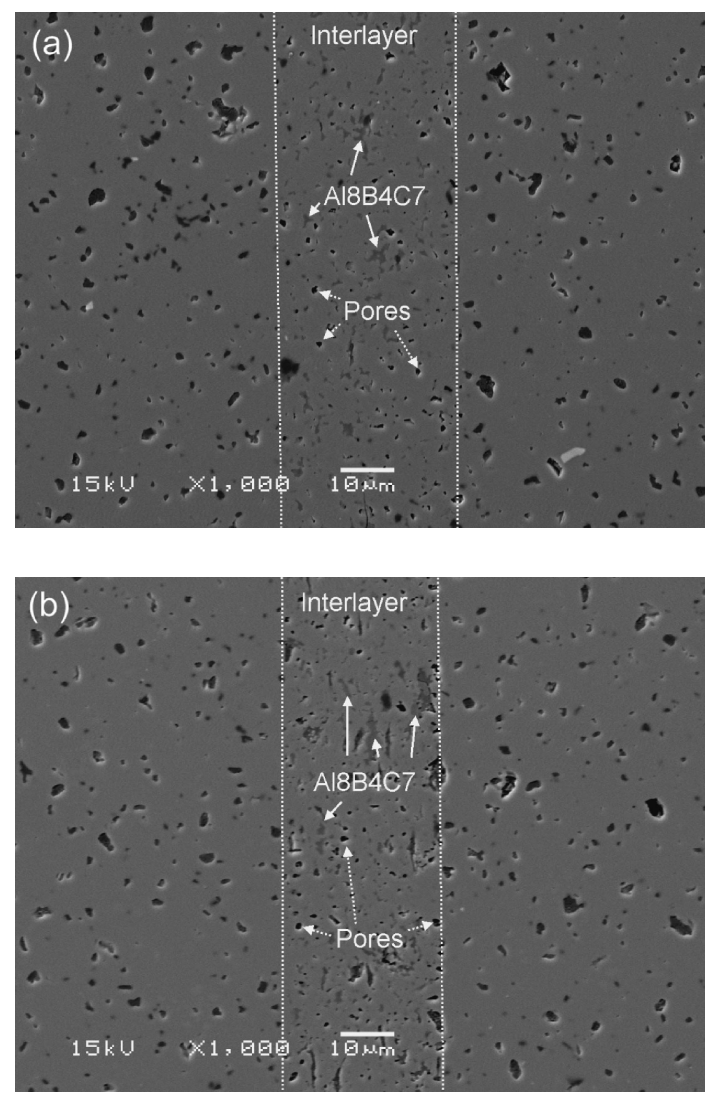

Fig. 6. Backscattered SEM images on the interlayer of (a) $\alpha$-A5BCC and (b) $\beta$-A5BCC started from $\alpha$-SiC (A-1) and $\beta$-SiC with $\mathrm{Al}-\mathrm{B}_{4} \mathrm{C}-\mathrm{C}$ additives (composition of $\mathrm{Al}: \mathrm{B}_{4} \mathrm{C}: \mathrm{C}=6: 1.3: 1.7$ ) and joined at $1850^{\circ} \mathrm{C}$ for $60 \mathrm{~min}$ under $15 \mathrm{MPa}$.

densification of $\mathrm{SiC}$ interlayer and iv) fine starting $\mathrm{SiC}$ powder readily produces dense interlayer for the joining of $\mathrm{SiC}$.

Based on these rules, we conducted a joining test at $1850^{\circ} \mathrm{C}$ that starts from tape-like joining material consisting of fine $\mathrm{SiC}\left(\beta\right.$-SiC) and $\mathrm{Al}-\mathrm{B}_{4} \mathrm{C}-\mathrm{C}$ additive (Table 3). The selected composition of $\mathrm{Al}: \mathrm{B}_{4} \mathrm{C}: \mathrm{C}=5: 1.3: 1.7$, corresponding to that of $\mathrm{Al}: \mathrm{B}: \mathrm{C}=5: 1: 2$, is based on above experiments and follows the chemical stoichiometry of $\mathrm{Al}_{8} \mathrm{~B}_{4} \mathrm{C}_{7}$ that is usually formed during the sintering of $\mathrm{SiC}^{21), 22)}$ aiming to decrease the amount of residual liquid phase after joining. The joining temperature is chosen for the crystallizing of grain-boundary phase. ${ }^{9)}$ For comparison, another tape-like joining material starting from $\alpha$-SiC powder was also used for the joining of SiC. As a result, we obtain nearly full dense SiC joints. The backscattered SEM images of the interlayer are shown in Fig. 6(a) and (b), where the gray $\mathrm{SiC}$ phase and the dark pores (indicated by dot white arrows) coexist with some dark gray phases (marked by solid white arrows) that distribute uniformly in the interlayer. The latter phase is most likely aluminum boron carbide in a formula of $\mathrm{Al}_{8} \mathrm{~B}_{4} \mathrm{C}_{7} \cdot{ }^{11), 21), 22)}$
The measured bending strengths of bonded $\mathrm{SiC}$ samples are also listed in Table 3 . We find that comparably high strengths of bonded $\mathrm{SiC}$ are obtained in both $\beta$-A5BCC ( $344 \pm 25 \mathrm{MPa})$ and $\alpha$-A5BCC (364 $\pm 24 \mathrm{MPa})$ by the selected joining parameters. The fracture of bonded $\mathrm{SiC}$ generally occurs within the $\mathrm{SiC}$ substrates, suggesting that the strength of joint is higher than that of host $\mathrm{SiC}$ ceramics. Note that the strength of $\mathrm{SiC}$ substrate probably degrades after joining process due to the heat cycle at $1850^{\circ} \mathrm{C}$ and the accompanying grain growth. Iseki et al. ${ }^{20), 21)}$ investigated the joining of two dense $\mathrm{SiC}$ sintered bodies with a mixture of $\beta$-SiC, $\mathrm{Al}, \mathrm{B}$ and $\mathrm{C}$ powders by hot-pressing at $1650^{\circ} \mathrm{C}$. It was found that the bending strength of bonded $\mathrm{SiC}$ at room temperature locates in the range from 200 to $530 \mathrm{MPa}$, varying with the additive composition. Present maximum joint strength is lower than $530 \mathrm{MPa}$ because the bonding strength is also associated with the properties of $\mathrm{SiC}$ substrates. It is therefore reasonable to suppose that higher-strength $\mathrm{SiC}$ joint can be produced by using stronger $\mathrm{SiC}$ sintered bodies or decreasing joining temperatures. This assumption is solid if referring to the work conducted by Morozumi, ${ }^{30)}$ in which it was found that the sintering additives and the fabrication process of monolithic $\mathrm{SiC}$ used to be joined have important effect on the bonding strength.

Finally, it is worth to emphasize the most important aspects of present work as follows: firstly, a new sintering additive $\mathrm{Al}-\mathrm{B}_{4} \mathrm{C}-\mathrm{C}$ is found to be feasible for the joining of $\mathrm{SiC}$ and shows comparable effect with $\mathrm{Al}-\mathrm{B}-\mathrm{C}$ additive that has been widely used to assist the densification of bulk $\mathrm{SiC}^{9), 31), 32)}$ and its jointing. ${ }^{20), 21)}$ Secondly, the tape-like joining materials show some advantages, such as formation of thin and dense interlayer, for the joining of $\mathrm{SiC}$ as compared with the powder-like. Tailoring the mechanical properties of $\mathrm{SiC}$ joints can be reached by controlling the fabrication of tapes. Most important, high strength of bonded $\mathrm{SiC}$ (>344 MPa) is achieved on the basis of an optimized joining parameter, suggesting that present joining method gives a candidate for the production of engineering components and structures.

At this time, we have investigated the effect of several important factors on the microstructure and properties of $\mathrm{SiC}$ joints. However, the effect of polytype transformation at high temperatures as starting from $\beta$-SiC powders and detailed tapecasting process on the microstructure of interlayer and the mechanical properties of SiC joints are not clear yet. From the points of view of energy saving and practical applications, low pressure or even pressureless joining are promising directions for the joining of SiC. Accordingly, following work will focus on these issues.

\section{Conclusion}

Joining tests of commercially available $\mathrm{SiC}$ ceramics by using powder- and tape-like joining materials that consist of $\mathrm{SiC}$ powder and $\mathrm{Al}-\mathrm{B}-\mathrm{C}$ or $\mathrm{Al}-\mathrm{B}_{4} \mathrm{C}-\mathrm{C}$ sintering additives were conducted in the temperature range of $1650-1850^{\circ} \mathrm{C}$ for $30-$ $60 \mathrm{~min}$ under a mechanical pressure of $12.5-50 \mathrm{MPa}$. SEM observations on the polished cross-sections of $\mathrm{SiC}$ joints 
demonstrate that i) the microstructure of interlayer is improved with the increasing $\mathrm{Al}$ content in $\mathrm{ABC}$ at $1650^{\circ} \mathrm{C}$ while degraded in sample $\mathrm{A} 6 \mathrm{BC}$ at $1750^{\circ} \mathrm{C}$, ii) tape-like joining materials is favorable for diminishing the pores inside interlayer, iii) sintering additive $\mathrm{Al}-\mathrm{B}_{4} \mathrm{C}-\mathrm{C}$ is found to be feasible for the joining of $\mathrm{SiC}$ and shows comparable effect with additive $\mathrm{Al}-\mathrm{B}-\mathrm{C}$ and iv) fine staring $\mathrm{SiC}$ powder readily results in dense interlayer for the joining of SiC. By using an optimized joining process, a nearly full dense $\mathrm{SiC}$ joints is obtained and high strength over $344 \mathrm{MPa}$ is achieved.

Acknowledgements The present research was carried out with financial aid from New Energy and Industrial Technology Development Organization (NEDO) as part of the "Innovative Development of Ceramics Production Technology for Energy Saving". The authors would like to appreciate NEDO and all the other related parties for their support.

\section{References}

1) G. W. Meetham, J. Mater. Sci., 26, 853-860 (1991).

2) T. F. Cooke, J. Am. Ceram. Soc., 74, 2959-2978 (1991).

3) S. Zhu, M. Mizuno, Y. Kagawa and Y. Mutoh, Compos. Sci. Technol., 59, 833-851 (1999).

4) J. Nadeau, Am. Ceram. Soc. Bull., 52, 170-174 (1973).

5) S. Prochazka and R. Scanlan, J. Am. Ceram. Soc., 58, 72 (1975).

6) S. Prochazka, The role of boron and carbon in the sintering of silicon carbide, in "Special Ceramics," ed. by P. Popper, British Ceramic Research Association, Stoke-on-Trent, England (1975) pp. 171-181.

7) S. Shinozaki, R. M. Williams, B. N. Juterbock, W. T. Donlon, J. Hangas and C. R. Peters, Am. Ceram. Soc. Bull., 64, 13891393 (1985).

8) J. J. Cao, W. J. MoberlyChan, L. C. DeJonghe, C. J. Gilbert and R. O. Ritchie, J. Am. Ceram. Soc., 79, 461-469 (1996).

9) X. F. Zhang, Q. Yang and L. C. De Jonghe, Acta Mater., 51, 3849-3860 (2003).

10) M. E. Sixta, X. F. Zhang and L. C. De Jonghe, J. Am. Ceram.
Soc., 84, 2022-2028 (2001).

11) Y. Zhou, H. Tanaka, S. Otani and Y. Bando, J. Am. Ceram Soc., 82, 1959-1964 (1999).

12) H. Tanaka and Y. Zhou, J. Mater. Res., 14, 518-522 (1999).

13) D. A. Ray, S. Kaur, R. A. Cutler and D. K. Shetty, J. Am. Ceram. Soc., 91, 2163-2169 (2008).

14) S. Lee, H. Tanaka and Y. Kagawa, J. Eur. Ceram. Soc., 29, 2087-2095 (2009).

15) R. Loehman and A. Tomsia, Am. Ceram. Soc. Bull., 67, 375380 (1988).

16) J. Fernie, R. Drew and K. Knowles, Int. Mater. Rev., 54, 283331 (2009).

17) D. DeLeeuw, J. Am. Ceram. Soc., 75, 725-727 (1992).

18) J. Zheng, Ö. Ünal and M. Akinc, J. Am. Ceram. Soc., 83, 1687-1692 (2000).

19) J. Zheng and M. Akinc, J. Am. Ceram. Soc., 84, 2479-2483 (2001).

20) T. Iseki, K. Arakawa and H. Suzuki, J. Mater. Sci., 15, 10491050 (1980).

21) T. Iseki, K. Arakawa, H. Matuzaki and H. Suzuki, Yogyo Kyokaishi, 91, 349-354 (1983).

22) B. Lin, M. Imai, T. Yano and T. Iseki, J. Am. Ceram. Soc., 69, C67-C68 (1986)

23) B. H. Rabin, J. Am. Ceram. Soc., 73, 2757-2759 (1990).

24) B. H. Rabin, J. Am. Ceram. Soc., 75, 131-135 (1992).

25) T. J. Perham, L. C. De Jonghe and W. J. MoberlyChan, J. Am. Ceram. Soc., 82, 297-305 (1999).

26) H. Yan, W. R. Cannon and D. J. Shanefield, J. Am. Ceram. Soc., 76, 166-172 (1993).

27) S. M. Olhero, P. Miranzo and J. M. F. Ferreira, J. Eur. Ceram. Soc., 26, 2475-2483 (2006).

28) J. C. Viala, J. Bouix, G. Gonzalez and C. Esnouf, J. Mater. Sci., 32, 4559-4573 (1997).

29) W. Kingery, H. Bowen and D. Uhlmann, "Introduction to Ceramics," Vol., John Wiley \& Sons, New York (1960).

30) S. Morozumi, J. Nucl. Mater., 169, 270-272 (1989).

31) A. M. Kueck and L. C. De Jonghe, J. Eur. Ceram. Soc., 28, 2259-2264 (2008).

32) K. S. Cho, Z. A. Munir and H. K. Lee, J. Ceram. Process. Res., 9, 500-505 (2008). 